\title{
Influencing Work-Related Learning: The Role of Job Characteristics and Self-Directed Learning Orientation in Part-Time Vocational Education
}

\author{
David Gijbels • Isabel Raemdonck • Dries Vervecken
}

Received: 7 September 2009 / Accepted: 26 May 2010 /

Published online: 9 June 2010

C The Author(s) 2010. This article is published with open access at Springerlink.com

\begin{abstract}
Based on the Demand-Control-Support (DCS) model, the present paper aims to investigate the influence of job characteristics such as job demands, job control, social support at work and self-directed learning orientation on the workrelated learning behaviour of workers. The present study was conducted in a centre for part-time vocational education in Flanders (Belgium). The students in the centre work for 3 days a week and attend school during the other two days. A questionnaire using scales adapted from validated instruments was used. Students were asked to complete the questionnaire with the job in mind they were doing at present. A total of 115 students from different sectors completed the questionnaire. It was assumed that high scores for self-directed learning orientation and high scores for the job characteristics job demands, job control and social support would be associated with more workrelated learning behaviour. All scales had acceptable Cronbach alpha values. The results of the linear regression analyses indicated that only the self-directed learning orientation scale predicted the work-related learning behaviour to a significant extent.
\end{abstract}

Keywords Work-related learning · Part-time vocational education ·

Self-directed learning · Job characteristics

\section{Introduction}

In today's rapidly evolving society, we are confronted with an exponential increase in information, a growing need for innovation and the requirement to develop

\footnotetext{
D. Gijbels $(\bowtie)$

Institute for Education and Information Sciences, University of Antwerp, Venusstraat 35,

BE2000 Antwerp, Belgium

e-mail: david.gijbels@ua.ac.be

I. Raemdonck

University of Leiden, Leiden, The Netherlands

D. Vervecken

Free University of Berlin, Berlin, Germany
} 
sufficient skills. Schools, enterprises, and players in the field of training and development are faced with the challenge of finding, valuing and further developing every talent. The high level of competence and the innovative capacity on which the economy is based are strongly determined by the development and training which employees have undergone (Tynjälä 2008). With regard to this, today's employers report that students who have completed vocational training courses have too little transferable knowledge and too few transferable skills to be productive (Streumer and van der Klink 2001). Researchers such as Resnick (1987) and Baldwin and Ford (1988) have long argued that what is taught in school is too remote from everyday work practice and no longer provides adequate preparation for the labour market.

Teaching and training in the workplace is one of the most important tools for improving the difficult connection between education and the labour market. As a result, the value which is placed upon learning in the workplace has increased. In the case of workplace learning, both explicit and implicit or tacit knowledge is developed (Eraut 2004; Smith 2001). Everyday work practice is full of potential learning processes. These can be very effective and necessary for the purposes of becoming more expert at your profession. Learning often takes place without one being aware of it, by making mistakes and redoing, talking with colleagues, observing, reading and listening to others. This informal learning in everyday work situations can be very effective and necessary for students from the vocational education sector. With the recognition of this, learning and work become an integral part of each other (Doornbos et al. 2004). How informal learning can to be stimulated so that a powerful learning work environment is created is a matter for which educators and HRD professionals are responsible.

This study examines the influence of the job characteristics of a training placement and a self-directed learning orientation on work-related (informal) learning in pupils from the part-time education sector. Pupils between the ages of 15 and 22 belong to a group in which the increase in knowledge through work is greatest (Borghans et al. 2006). By work-related learning, we mean the extend to which people participate on the job in activities that offer opportunities for learning, such as looking for new information, looking for solutions for new problems, performing new tasks what is learnt on the job. Learning from doing work itself. By handling a particular job situation and particular tasks, it is also possible to learn operations and strategies and to acquire knowledge.

\section{Job Characteristics and Work-Related Learning}

The characteristics of the work which is done by pupils determine the quality of the learning workplace. From the literature, it is apparent that job characteristics such as job demands and job control are related to negative outcomes such as tension, work stress and dissatisfaction with work (e.g. de Jonge et al. 2003). Recently, research has also been done into job characteristics as determinants of positive outcomes such as well-being, self-confidence and active learning behaviour. Insight into the role of job characteristics is, therefore, of great importance. Karasek's demand-control model (DC model) and the derived demand-control-support model (DCS model) are leading models in research into the psychology of work (Taris et al. 2003) that predict, as an exception to the rule, negative (stress) as well as positive outcomes 
(learning) as a function of specific combinations of job characteristics. The DC model assumes that a work environment can be described in two dimensions: psychological job demands on the one hand and job control on the other (see Fig. 1).

Job demands (horizontal axis) refer to stress factors which are present in the work environment. Here we think of work pressure, for example work pressure is high because of high time pressure, which means that a high work rate prevails. It is a matter of how much work has to be done and what time is available in which to do it. A demanding job thus means that someone has to complete a great deal of work within a limited space of time (De Witte et al. 2005). Job control (vertical axis) refers to the opportunities which an employee has to satisfy these job demands. These opportunities are represented by the scope the employee has for taking decisions for himself (decision authority) and the scope that exists for making use of his own skills (skill discretion) (De Witte et al. 2005).

In this system of axes, the two diagonal axes constitute the basic assumptions of the model. The first diagonal, which Karasek (1979; Karasek and Theorell 1990) calls the strain diagonal, gives the extent of the risks of psychological stress. High stress risks are to be found with high job demands and low job control. This combination results in a low sense of well-being and health problems. These are what are known as high-strain jobs. We can also classify this axis as being an indication of health. Stress reactions will occur when both dimensions (job demands and control) are out of balance. An increase in job demands is problematic if it is not possible to respond to them in an appropriate way, i.e. if there is a low amount of job control. The underlying thought is that high job demands cause 'arousal', which results in stress if no effective coping strategy can be developed to meet the high job demands (Karasek and Theorell 1990). At the other end of the diagonal, we find a work situation with low job demands and high job control (low-strain jobs). In this situation, we expect a lower than average level of risks of stress, as there are ample opportunities for being able to cope with the job demands (De Jonge et al. 2003; Taris et al. 2003).

The second diagonal (learning opportunities) embodies the learning hypothesis and has to do with motivation/activation and learning behaviour. A work situation offers more learning potential if the dimensions of job demand and job control are in balance. Here, an employee has sufficient opportunities to adjust successfully to the challenges arising from the work situation. Such situations are called 'active learning behaviour'. Taris and Kompier (2005) conclude that, according to Karasek, this means the learning of new skills and behaviours as well as the effective solution of

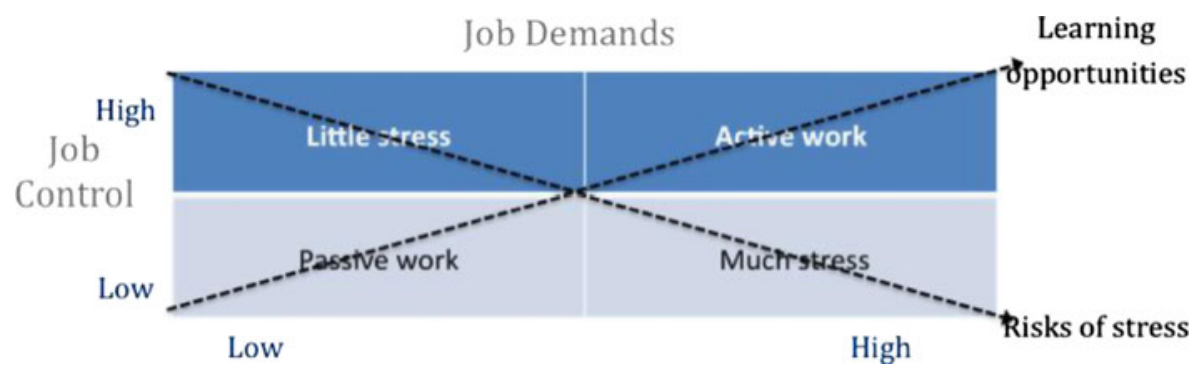

Fig. 1 The demand-control model (after Karasek 1979) 
problems, work commitment and motivation (De Witte et al. 2005). In this case, the employee has a great deal of job control and can, in a demanding work situation (high job demands), try out different ways of solving problems at work. In this way, it is possible to acquire new skills.

At the other end of the diagonal, the opposite situation can be found. Few job demands and low job control result in a passive situation. The low job demands ensure that little tension is experienced and the low job control offers few opportunities for growth and development.

To sum up, it is possible to distinguish between four quadrants in this model. Low job demands combined with much job control produce a work situation with little stress (low-strain jobs). High job demands and little job control produce a work situation with much stress and a high risk of stress reactions (high-strain jobs). A passive work situation exists where little job control is given to an employee together with low job demands (passive jobs). And, lastly, there is the active variant in which learning is possible as a result of high job demands combined with a high degree of job control (active jobs).

In this way, the diagonals can each be divided into two main effects and an interactive effect. For example, the learning hypothesis assumes more learning opportunities with an increase in job demands, which we see, for example, confirmed in Skule (2004). The same effect is also expected with an increase in job control. Lastly, an interactive effect is assumed to exist, which results in the greatest learning opportunity with high job demands and much job control.

By being implemented in practice, the model has acquired a third dimension, thanks to Johnson and Hall (1988). Work-related social support has proven to be an important interaction factor. By (work-related) social support we mean the existence of good relations with colleagues, being able to rely on others, obtaining accurate information via others, and gaining actual help, understanding and attention when difficulties are encountered (De Jonge et al. 2003). The nature of the way in which employees mutually support one another and the manner in which a person's superiors show their understanding will, to a considerable extent, determine whether the pressure of work will also actually develop into work stress. If social support is high, this is called a collective work situation. If it is low, this is called an isolated work situation. The most unfavourable effects on health are expected with a combination of high job demands, little job control and little social support: an isolated work situation with much stress (De Jonge et al. 2003). The most favourable effects on work-related learning are expected with a combination of high job demands, high job control and high social support.

\section{Criticism of the DCS Model}

Karasek's model has been criticised on several occasions, partly because of its popularity. As well as being a reason for its popularity, the simplicity of the model is directly source of criticism. What happens exactly? What processes are responsible for the effects described? The employee plays a passive role in the model and the person in question is never taken into consideration when trying to find an explanation. The extent to which interpersonal differences play a role is ignored (Taris et al. 2006). In the model, it is assumed that the work situation itself 
determines the effect, but research has shown that whether interactive effects exist between job demands and job control is wholly dependent on the presence or absence of certain personal characteristics (De Jonge et al. 2003). In this study of Karasek's learning hypothesis, Raemdonck et al. (2008) also criticised the absence of personal characteristics and included the factor of a self-directed learning orientation in the model as a predictor of work-related learning.

\section{A Self-Directed Learning Orientation and Work-Related Learning}

As a response to rapid evolution, it is not just a quality work environment which is of importance; equally important is how the individual copes with these successive changes. The development and fruition of the knowledge economy and numerous technological changes not only require more highly-trained workforces, modern employees are also expected to be willing to continue to learn (Abele and Wiese 2008). The notion of lifelong learning has become generally accepted by policy makers, educators, trainers and researchers (Boekaerts 1999; Brockett et al. 2000). An attitude of continual learning requires self-direction and flexibility. The development of a self-directed learning orientation is thus also an important competence for students from the vocational education sector. Self-directed learning orientation is defined as a relatively stable tendency to take an active and selfstarting approach to work-related learning activities and situations and to persist in overcoming barriers and setbacks (Raemdonck et al. 2008; Seibert et al. 2001). Employees with a self-directed learning orientation identify learning opportunities, show learning initiative, undertake learning activities, and persevere in overcoming barriers to learn. In contrast, people who are less oriented towards self-directed learning exhibit the opposite behaviour: they fail to identify learning opportunities, let alone seize opportunities to learn, (Seibert et al. 2001). According to Taris and Kompier (2005, p. 153) taking a self-starting approach towards learning means that the goals of one's actions are not determined by someone else, but rather that one develops one's own goals. Having an active approach to learning implies that one acts proactively, tries to detect possible problems that may hinder learning and develops action plans to prevent such problems from occurring. As self-directed learning orientation is found in persons who actively shape learning activities and situations we expect employees with a self-directed learning orientation to exhibit more actual work-related learning. In vocational practice, it would seem plausible that students also differ in the degree to which they make use of learning opportunities in the work environment, and, accordingly, that given particular job characteristics, some students may learn more then other students (Taris and Kompier 2005). Especially students oriented towards self-direction, might learn more in the workplace.

Over the years, the concept of self-direction in learning has been studied in a variety of domains and disciplines and has been conceptualised differently. Selfdirected learning is mainly used to describe a process-oriented approach to learning (Long 1989). In this study, self-direction is approached as a personal attribute referring to a personal quality or characteristic of learners (Brockett and Hiemstra 1991; Candy 1991; Garrison 1997; Oddi 1984; Merriam and Caffarella 1999). In conceptualizations in which self-direction is approached as a personal characteristic, 
Brockett and Hiemstra (1991, p. 29) argue that self-direction points to an individual's beliefs and attitudes, intentions and behaviour that predispose one toward taking primary responsibility for personal learning endeavours (Brockett and Hiemstra 1991, p. 29). By including self-direction in this study, we can examine whether individual differences (in this case, the extent to which there is an orientation towards self-direction) are able to explain matters that have only been explained by external situation factors in the case of Karasek and whether selfdirection in specific may influence the strength of the link between job characteristics and work-related learning. In this way, we come a bit closer to countering the criticism that the original model does not take account of personal differences.

In conclusion, we can state that too little research has been done into Karasek's learning hypothesis up until now. This is a gap in the field of research and is extremely relevant. For example, Parker and Sprigg (1999, in Taris and Kompier 2005) state that different management philosophies and practices show the competitive advantage of the better use of human capital within an organisation. They are in favour of promoting the development of self-direction, learning-oriented employees and the development of a powerful learning environment, and they emphasise the value of research into the work-related conditions that hinder or strengthen the learning of the employee. Research into the learning hypothesis and the role of a self-directed learning orientation can benefit targeted investments in a high-quality learning work environment.

As has already been stated, the DCS model does not take account of interpersonal differences. Investigators such as Parker and Sprigg (1999) and De Rijk et al. (1998) have already shown that it is possible to produce more carefully detailed reports of the influence of job characteristics if account is taken of personal characteristics. Consequently, we will include the personal characteristic of a self-directed learning orientation. In so doing, we attempt to explain some of the differences between people with regard to work-related learning.

\section{Research Questions}

The aim of this study is to examine the relation between the independent variables of a self-directed learning orientation, job demands, job control and job support and the dependent variable of work-related learning behaviour. The study model is shown as Fig. 2.

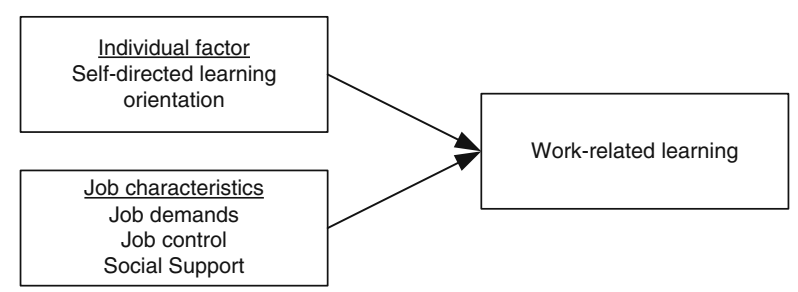

Fig. 2 Research model determinants of work-related learning 
The following research questions are central to this:

1. Is self-directed learning orientation positively related to the work-related learning of students in part-time vocational education?

2. Are job demands positively related to work-related learning?

3. Is job control positively related to work-related learning?

4. Is social support positively related to work-related learning

\section{Method}

\section{Respondents}

The questionnaires were administered to students $(N=115)$ from three schools providing part-time education. As not all students from the part-time secondary vocational education have jobs, only students who had a job contract as part of their training were questioned for the study. The study includes students from the different training "rubrics" which are offered by the Flemish part-time educational system: woodwork $(9.6 \%)$, catering industry $(10.5 \%)$, metal industry $(10.5 \%)$, Business and administration (7.8\%). Participants represented several training sectors (e.g. Assistent cook, kitchenstaff within catering rubric) from which the rubrics are composed. Table 1 provides a full overview of the sample distribution. The age of the respondents ranges from 15 to $22,49.6 \%$ are women and $50.4 \%$ are men.

The questionnaire was administered by one member of the research team during class. The completion of the questionnaires was always preceded by an introductory talk. In this way, an attempt was made to make the study more relevant for the respondents in order to increase the commitment of the participants and guarantee optimal validity. On beforehand, the usability of the questionnaire was tested with nine students from the part-time education sector by having them complete the questionnaires and asking whether they contained any difficult words and whether all of the questions were understandable.

\section{Measures}

Job Characteristics For the measurement of the DCS characteristics, we selected items from existing questionnaires of De Jonge et al. (1994), Hackman and Oldham (1975), Karasek (1985), and Warr (1990). The three characteristics are measured using five-point Likert scales, which range from one for strongly disagree to five for strongly agree. Job control is measured using a scale that consists of ten items. Only the aspect 'decision authority' is measured here (see above). This is the amount of say an employee has in his job. The respondent is asked about the extent to which the job that the students perform at their learning workplace provides them with the opportunity to "stop working when they like" or "to determine their own way of working". Job demands are measured by means of eleven items and refers to statements such as "My job requires that I work very hard", while questions are asked about social support on the basis of five items such as the statement "I receive much support from my colleagues". 
Table 1 Sample distribution according to rubrics and training sectors in Flemish part-time education

\begin{tabular}{|c|c|c|c|c|c|}
\hline Rubrics & $\mathrm{n}$ & $(\%)$ & Training sector & $\mathrm{n}$ & $(\%)$ \\
\hline \multirow[t]{2}{*}{ Catering } & 12 & $(10.5)$ & Assistent Cook & 4 & $(3.5)$ \\
\hline & & & Hall and kitchen staff & 8 & $(7)$ \\
\hline \multirow[t]{2}{*}{ Human Caring } & 8 & $(6.9)$ & Logistic helper & 3 & $(2.6)$ \\
\hline & & & Care worker & 5 & $(4.3)$ \\
\hline Metal & 12 & $(10.5)$ & Welding & 12 & $(10.5)$ \\
\hline \multirow[t]{3}{*}{ Business and Administration } & 9 & $(7.8)$ & Administrative secretary & 4 & $(3.5)$ \\
\hline & & & Office employee & 2 & $(1.7)$ \\
\hline & & & Salesperson & 3 & $(2.6)$ \\
\hline \multirow[t]{4}{*}{ Construction } & 50 & $(43.6)$ & Roof & 3 & $(2.6)$ \\
\hline & & & Road & 4 & $(3.5)$ \\
\hline & & & Industrial & 1 & $(0.9)$ \\
\hline & & & Construction & 42 & $(36.6)$ \\
\hline Wood & 11 & $(9.6)$ & Carpenting & 11 & $(9.6)$ \\
\hline Maintenance & 3 & $(2.6)$ & Maintenance worker & 3 & $(2.6)$ \\
\hline Cultivation and gardening & 1 & $(0.9)$ & Agriculture & 1 & $(0.9)$ \\
\hline Environment & 3 & $(2.6)$ & Environment & 3 & $(2.6)$ \\
\hline Grafical design & 1 & $(0.9)$ & Light publicity & 1 & $(0.9)$ \\
\hline Transportation & 1 & $(0.9)$ & Cars & 1 & $(3.5)$ \\
\hline Missing & 4 & $(3.5)$ & & & \\
\hline Total & 115 & $(100)$ & & 115 & $(100)$ \\
\hline
\end{tabular}

Self-Directed Learning Orientation The self-directed learning orientation scale is an eleven-item scale developed on the basis of the short version of the Proactive Personality Scale of Bateman and Crant (1993) and the Personal Initiative Scale of Frese et al. (1997). Empirical evidence demonstrates that self-directed learning orientation is a uni-dimensional construct (see Raemdonck 2006). Examples of items are "A difficult task does not hold me back" and "I am constantly looking for new ways of improving my job performance". Participants were asked to indicate on a five-point scale (ranging from one $=$ strongly disagree to five $=$ strongly agree) to what extent each statement was applicable to them.

Work-Related Learning is measured on the basis of a self-developed instrument. In ten items, the respondents were asked about the frequency with which they had actually participated in certain work-related learning activities during the past year, for example the acquisition of new information, the finding of solutions to problems, and the performance of new tasks. This is measured on a 4-point scale ranging from one (almost) never to four (almost) always. An exploratory factor analysis with a main components extraction and Varimax rotation for the ten items en masse, showed that all items loaded on one and the same factor which explained circa $40 \%$ of variance. Factor loadings for the ten manifest variables ranged from .580 till .731. Also content wise, these ten items like; "learning new things", "creating new ideas", 
"looking for new information", seem to reflect several aspects of work-related learning behaviour.

Furthermore, some control variables such as the number of months' work experience acquired during the part-time learning programme, age, training sector, career prospects (for example, desire to have a higher, lower or equivalent job position in future), did the person choose the learning workplace himself or was it assigned, and possible relevant subsidiary activities such as following courses or training, relevant to the job are included.

\section{Analyses}

Correlation analysis and linear regression were applied to analyze the main model. In order to examine the influence of the control variables, dummy variables were generated for the categorical variables (chosen oneself, gender, relevant training, and career prospects). This made it possible to add these dummies to the main model and to continue with a linear regression analysis. In order to analyse the suggested interaction influence between job demands, job control and social support, interaction terms with dummies were prepared.

\section{Results}

\section{Descriptives}

There was a noticeably high score for the personal characteristic 'self-directed learning orientation' (see Table 2). With regard to the job characteristics, it is noticeable that social support at work gets a high score. Students often state that they "receive support from their colleagues to get their work done". Mutual relations between colleagues are good and their superiors appear to be an encouraging influence in many cases. It appears that the average student from the part-time vocational education sector does not have a great say (job control) in his work tasks. With an average of 2.69 for control on a scale ranging from one to five, the half-way mark is not reached. Most respondents are of the opinion that they have few opportunities to determine the nature of the work and the amount of work over a particular period. The job demands tend to be rather high in the view of the students. This characteristic obtains an average score that lies just above the median (3.30 on a scale of one to five).

Table 2 Averages, reliability, standard deviations and number of items per scale

\begin{tabular}{lcccc}
\hline & Mean & $\alpha$ & SD & Number of items \\
\hline Job demands & 3.30 & .72 & .58 & 11 \\
Job control & 2.69 & .79 & .69 & 10 \\
Social support & 3.98 & .79 & .73 & 5 \\
Self-directed learning orientation & 3.74 & .83 & .54 & 11 \\
Work-related learning behaviour & 2.55 & .83 & .49 & 10 \\
\hline
\end{tabular}


It is apparent from the correlations in Table 3 that two independent variables correlate in a significant and positive way with the dependent variable of workrelated learning behaviour: self-directed learning orientation and job demands. The independent variables of 'job control' and 'social support' are not significantly correlated with the dependent variable of 'work-related learning'. Furthermore, Table 3 shows that 'self-directed learning orientation' and 'job demands', 'selfdirected learning orientation' and 'social support', and 'job demands' and 'social support' are significantly correlated with each other. These correlations are also positive and moderate to strong (between 0.30 and 0.50 ).

\section{Predictors of Work-Related Learning}

A linear regression has been carried out in order to discover what influence the job characteristics and self-directed learning orientation have on work-related learning behaviour. In Table 4, the standardised regression weightings for the four independent variables are included. These relate to the three job characteristics of job demands, job control and social support and the personal characteristic of selfdirected learning orientation. These constitute the main model as shown in Fig. 2.

This main model is able to explain $19.3 \%$ of the variance within work-related learning, as can be seen in Table 4. Self-directed learning orientation appears to be the greatest and only significant predictor of work-related learning. An increase of one point on the scale of self-directed learning orientation is associated with an increase of 0.412 on the scale for work-related learning. From this analysis, the job characteristics (demands, control and support) appear to have no significant positive influence on work-related learning behaviour.

Compared with the variable of self-directed learning orientation, the influence of the job characteristics is rather modest and not significant. Noticeable is the small negative effect of social support on work-related learning. The support that students receive from their colleagues appears not to stimulate their work-related learning in the learning workplace. The effects of job demands and job control are certainly positive, but not significant with regard to work-related learning. The influence of job demands (e.g. time pressure) is greater than the effect of job control (e.g. taking decisions oneself) over work-related learning.

Table 3 Correlations between 4 independent variables and work-related learning behaviour

\begin{tabular}{lccccc}
\hline & $\begin{array}{c}\text { Self-directed learning } \\
\text { orientation }\end{array}$ & Demands & Control & Support & $\begin{array}{c}\text { Work-related learning } \\
\text { behaviour }\end{array}$ \\
\hline $\begin{array}{l}\text { Self-directed learning } \\
\text { orientation }\end{array}$ & 1 & $.411^{\mathrm{a}}$ & $.197^{\mathrm{a}}$ & $.317^{\mathrm{a}}$ & $.485^{\mathrm{a}}$ \\
$\begin{array}{l}\text { Demands } \\
\text { Control }\end{array}$ & 1 & .053 & $.316^{\mathrm{a}}$ & $.287^{\mathrm{a}}$ \\
Support & & 1 & $.218^{\mathrm{a}}$ & .122 \\
Work-related learning & & & 1 & .122 \\
\hline
\end{tabular}

${ }^{\text {a }}$ significant correlation $(p<0.05$, two-tailed $)$ 
Table 4 Standardised regression weightings for work-related learning

\begin{tabular}{lr}
\hline & Beta \\
\hline Self-directed learning orientation & $.412^{*}$ \\
Job demands & .157 \\
Job control & .082 \\
Social support & -.058 \\
$\mathrm{R}^{2}$ (Adjusted $\left.\mathrm{R}^{2}\right)$ & $.193 *$ \\
\hline$* p<.05$ &
\end{tabular}

According to Karasek's DCS model, active learning behaviour probably occurs more frequently in work situations that combine high demands, much control and much social support. In order to explore this hypothesis, interaction terms are added to the main model. None of these added interactions appears to exert a significant influence over work-related learning behaviour. The outcome of this analysis is presented in Table 5 .

After the analysis of this model, further analysis is carried out, in which control variables are added to the main model (see Table 6).

An Ancova analysis is carried out because of certain individual categorical control variables. This model is also significant and explains $31.7 \%$ of the variance within work-related learning. The analysis shows that the individual factor of 'selfdirected learning orientation' and the control variables of career prospects, 'working in another position at the same level' and 'expanding tasks within the current position' are significant. It is again also apparent from this analysis that self-direction has a positive effect on work-related learning. Furthermore, it is apparent that students who state that they want to work in 'another position at the same level' score significantly lower on work-related learning compared to students who prefer 'no change' in there current working position. However, students who state that they want to expand tasks within their current position score significantly higher on workrelated learning then the reference group (= students who prefer 'no changes' in their current working situation). The data are listed in Table 6.

Table 5 Standardised regression weightings for work-related learning with 2- and 3-way interactions

\begin{tabular}{lr}
\hline & Beta \\
\hline Self-directed learning orientation & $.370^{*}$ \\
Job demands & -.545 \\
Job control & -.884 \\
Social support & -.053 \\
Job demands*Job control & 1.111 \\
Job demands*Social support & .017 \\
Job demands*Job control*Social support & .093 \\
$\mathrm{R}^{2}$ (Adjusted $\mathrm{R}^{2}$ ) & $.186^{*}$ \\
\hline
\end{tabular}

${ }^{*} p<.05$ 
Table 6 Effect sizes for all independent variables with regard to work-related learning behaviour on the basis of Ancova analysis

B

\begin{tabular}{lc}
\hline Self-directed learning orientation & $.341^{*}$ \\
Job demands & .122 \\
Job control & .038 \\
Social support & -.004 \\
Workplace chosen oneself & -.047 \\
Man & -.178 \\
No relevant preliminary training & .068 \\
Career prospects & \\
other position at higher level vs no change & .079 \\
other position at same level vs no change & $-.434^{*}$ \\
expansion of tasks within current position vs no change & $.391^{*}$ \\
Work experience & -.007 \\
Age & .126 \\
Different workplaces & -.032 \\
Adjusted Eta & \\
\hline
\end{tabular}

${ }^{*} p<.05$

Since it is apparent from the Ancova analysis that the effects of the variables of 'self-directed learning orientation' and 'career prospects' are significant, further linear regression analysis has been carried out with only these independent variables. Two dummy variables for 'career prospects' have been created as a preparation. The standardised regression weightings are included in Table 7. It is apparent from this analysis that the model is, in itself, significant and explains $22.1 \%$ of the variance within work-related learning behaviour. What is noticeable again is the large significant effect of a self-directed learning orientation.

Since it is apparent from linear regression analysis with control variables that only the individual factor of a 'self-directed learning orientation' has a significant influence on work-related learning behaviour, further linear regression analysis is carried out solely with this variable as an independent variable. The standardised

Table 7 Standardised regression weighting for self-direction and 2 Dummy control variables with regard to work-related learning behaviour and explained variance of the mode

Beta

Self-directed learning orientation

Career prospects

Dummy 1:expansion of tasks within current position

Dummy 2: other position at same level

$\mathrm{R}^{2}$ (adjusted $\mathrm{R}^{2}$ )

${ }^{*} p<.05$ 
regression weighting is included in Table 8. From this analysis, it is apparent that this personal characteristic is only capable of explaining $22.8 \%$ of the variance within work-related learning behaviour. From this study, a self-directed learning orientation appears to be the greatest and only significant predictor of work-related learning. An increase by one point in the self-directed learning orientation scale is associated with an increase of 0.485 in the scale of work-related learning.

\section{Conclusions and Discussion}

On the basis of the results of this study, no link has been established between job characteristics of the learning workplace and the work-related learning of students from the part-time vocational education sector. This is not what was expected. The assumption, based on the learning hypothesis of Karasek, was that high demands from the learning work environment, many opportunities for control over work tasks and much social support would show a positive link with work-related learning. However, on the basis of the study results, these three do not appear to have a significant positive influence.

On the basis of the respondents' perception of the employer's requirements and the degree of responsibility that they are given over their own jobs, we can only conclude that work-related learning is not optimally stimulated in current work placements for students from the part-time vocational education sector. Students are of the opinion that they are often given an opportunity to do different things at work, but they state that it is often a matter of performing the same tasks without doing much mentally exciting work and without having much responsibility. This is consistent with "passive work" according to Karasek's model (1979). We can only conclude from the results that, within the current work placements of students from the part-time vocational education sector, the learning potential is not always perceived as optimal.

The significant positive influence of a self-directed learning orientation confirms the expectation that individuals who are highly self-directed in their orientation towards learning also actually learn more in a work-related way. Consequently, it is important to develop the self-directability of students. In this way, this population of students can also acquire skills that can result in higher employability in the labour market as well as organisational success (Guglielmino and Guglielmino 1994; Jackson 1996; Raemdonck and Thijssen 2005; Van Loo 2005).

Our study shows that the work-related learning of students in vocational education relies on their personal characteristics. In future, it would be wise to explore the role of such personal characteristics in work-related learning further as

Table 8 Standardised regression weighting for self-direction with regard to work-related learning behaviour and explained variance of the model 
well as to look for possibilities for developing these personal characteristics at school and in on-the-job learning.

\section{Study Limitations}

Several limitations of this study are worth mentioning. First, a cross-sectional design was used. Potentially interesting questions regarding development over time of work-related learning were not able to be addressed (Taris et al. 2003). Secondly, all variables measured in this research were obtained through self-reports. Due to the limited literacy of this specific population, misinterpretations of the statements could have occurred. The magnitude of the effects reported may have been biased due to common-method variance.

Thirdly, the current study involved a sample of students from only three schools in the vocational education sector in one region, so the sample is more or less homogeneous. The students worked in different workplaces, so there is variation in their job characteristics.

Fourthly, because most of the pupils in our sample $(N=115)$ had low job control, we had to deal with unbalanced cell sizes. This makes it hard to conduct significant interaction analysis. On the basis of these results, it would, therefore, not be appropriate immediately to dismiss the learning hypothesis of Karasek. Insufficient respondents soon result in insignificant results (in interaction terms).

\section{Implications}

Despite the limitations of the present study, some important implications can be drawn. The highest levels of work-related learning are found in those students who show a high orientation towards self-directedness in learning. Therefore, the stimulation of selfdirected learning orientation should be maximised in the workplace and at school. Better information regarding "learning on the job" can be made available to students, workers and managers of employing organizations as a result of a greater co-operation with vocational education and training providers. The provision of the part-time vocational education can also be more focused on the teaching and development of this self-directed learning competence, including learning how to learn.

From the results, it appears that students from the part-time vocational education sector on average attribute high scores to social support. They are of the opinion that they receive a great deal of support. Despite the support they receive in the workplace, this does not appear to have the effect of stimulating work-related learning. There is a risk of students developing undesirable action plans as a result of 'wrong support' (Taris 2007). Therefore, 'negative' social support should be prevented. In this way, one can minimise the negative effects of it on workplace learning. It would appear desirable to look for systems which enable students to receive and give 'accurate feedback' at times when this is necessary. In this way, students can develop 'appropriate action plans'. For this, clear agreements and cooperation with the organisations that provide the work is essential.

Our findings hardly support the views of Karasek and Theorell for students in part-time vocational education. The beneficial effects of high job demands, high job control and high social support were not confirmed. Instead, a self-directed learning 
orientation was associated with higher levels of work-related learning. It would be interesting to see whether these results can be replicated beyond the context of parttime vocational education and within different professions. Future longitudinal studies will have to verify the results found in this study.

Acknowledgements The authors are grateful to Jonas Van Herck for his co-operation in this research project.

Open Access This article is distributed under the terms of the Creative Commons Attribution Noncommercial License which permits any noncommercial use, distribution, and reproduction in any medium, provided the original author(s) and source are credited.

\section{References}

Abele, A. E., \& Wiese, B. S. (2008). The nomological network of self-management strategies and career success. Journal of Occupational and Organizational Psychology, 81, 733-749.

Baldwin, T. T., \& Ford, J. K. (1988). Transfer of training: a review and directions for future research. Personnel Psychology, 411, 63-105.

Bateman, T. S., \& Crant, J. M. (1993). The proactive component of organizational behaviour: a measure and correlates. Journal of Organizational Behavior, 14, 103-118.

Boekaerts, M. (1999). Self-regulated learning: where we are today. International Journal of Educational Research, 31, 445-457.

Borghans, L., Golsteyn, J., \& De Grip, A. (2006). Meer leren door meer werken. [Learning more by working more]. Den Bosch: CINOP.

Brockett, R. G., \& Hiemstra, R. (1991). Self-direction in adult learning: Perspectives on theory, research, and practice. New York: Routledge, Chapman, and Hall.

Brockett, R. G., Stockdale, S. L., Fogerson, D. L., Cox, B. F., Canipe, J. B., Chuprina, L. A., et al. (2000, February). Two decades of literature ons elf-directed learning: a content analysis. Paper presented at the International Self-directed Learning Symposium. Florida. (ERIC document No ED449348).

Candy, P. C. (1991). Self-direction for lifelong learning: A comprehensive guide to theory and practice. San Francisco: Jossey-Bass.

De Jonge, J., Landeweerd, J. H., \& Van Breukelen, G. J. P. (1994). 'De Maastrichtse Autonomielijst: Achtergrond constructie en validering' [The Maastricht autonomy list: background, construction and validation]. Gedrag en Organisatie, 7(1), 27-41.

de Jonge, J., Bakker, A., \& Schaufeli, W. (2003). Psychosociale Theorieën over werkstress. [Psychosocial theories of work stress]. Houten: Bohn Stafleu van Loghum.

De Rijk, A. E., Le Blanc, P. M., Schaufeli, W. B., \& de Jonge, J. (1998). Active coping and need for control as moderators of the job demand-control model: Effects on burnout. Journal of Occupational and Organizational Psychology, 71, 1-18.

De Witte, H., Verhofstadt, E., \& Omey, E. (2005). "Testing Karasek's learning and strain hypothesis on young workers in their first job", Working Paper, Faculteit Economie en Bedrijfskunde [Faculty of Economics and Business Studies], Universiteit Gent [University of Ghent] , no. 2005/326, 27 p.

Doornbos, A. J., Bolhuis, S. M., \& Simons, P. R. J. (2004). Modeling work-related learning on the basis of intentionality and developmental relatedness: a non-educational perspective. Human Resource Development Review, 3(3), 250-274.

Eraut, M. (2004). Informal learning in the workplace. Studies in Continuing Education, 26(2), 247-273.

Frese, M., Fay, D., Hilburger, T., Leng, K., \& Tag, A. (1997). The concept of personal initiative: operationalization, reliability, and validity in two German samples. Journal of Occupational and Organizational Psychology, 70, 139-161.

Garrison, D. R. (1997). Self-directed learning: toward a comprehensive model. Adult Education Quarterly, 48(1), 18-33.

Guglielmino, L. M., \& Guglielmino, P. J. (1994). Practical experience with self-directed learning in business and industry human resource development. In R. Hiemstra \& R. G. Brockett (Eds.), Overcoming resistance to self-direction in aduli learning. New Directions for Adult and Continuing Education, no. 64. San Francisco: Jossey-Bass.

Hackman, J. R., \& Oldman, G. R. (1975). Development of the Job Diagnostic Survey. Journal of Applied Psychology, 60, 159-170. 
Jackson, C. (1996). Managing and developing a boundaryless career: lessons from dance and drama. European Journal of Work an Organizational Psychology, 5(4), 617-628.

Johnson, J., \& Hall, E. (1988). Job strain, work place social support, and cardiovascular disease: a CrossSectional Study of a Random Sample of the Swedish Working Population. American Journal of Public Health, 78(10), 1336-1342.

Karasek, R. A. (1979). Job demands, job decision latitude, and mental strain: implications for job design. Administrative Science Quarterly, 24, 285-308.

Karasek, R. (1985). Job content questionnaire and user's guide. Lowell: University of Massachusetts Lowell, Department of Work Environment.

Karasek, R., \& Theorell, T. (1990). Healthy work. Stress, productivity and the reconstruction of working life. New York: Basic Books.

Long, H. B. (1989). Self-directed learning: Emerging theory and practice. In H. B. Long, \& Ass. (Eds.), Self-directed learning: Emerging theory and practice (pp. 1-11). Oklahoma: University of Oklahoma.

Merriam, S. B., \& Caffarella, R. S. (1999). Learning in adulthood, 2nd Edn. San-Fransisco, CA: JosseyBass.

Oddi, L. R. (1984). Development of an instrument to measure self-directed continuing learning (Doctoral dissertation, Northern Illinois University, 1984). Dissertation Abstracts International, 46(01A), 49.

Parker, S. K., \& Sprigg, C. A. (1999). Minimizing strain and maximizing learning: the role of job demands, job control, and proactive personality. Journal of Applied Psychology, 84, 925-939.

Raemdonck, I. (2006). Self-directedness in learning and career processes. A study in lower-qualified employees in Flanders. Ghent: Faculty of Psychology and Educational Sciences, Ghent University.

Raemdonck, I., \& Thijssen, J. (2005). Lifelong learning and employability. Lifelong Learning in Europe, 10(2), 66-69.

Raemdonck, I., Plomp, I., \& Segers, M. (2008). Obsolete or up-to-date? The role of job characteristics and self-directed learning orientation. Paper presented at the 4th EARLI SIG 14 Learning and Professional Development Conference. 27th-29th August, University of Jyväskylä, Finland.

Resnick, L. B. (1987). Learning in school and out. Educational Researcher, 16(9), 13-20.

Seibert, S. E., Kraimer, M. L., \& Crant, J. M. (2001). What do proactive people do? A longitudinal model linking proactive personality and career success. Personnel Psychology, 54, 845-874.

Skule, S. (2004). Learning conditions at work: a framework to understand and assess informal learning in the workplace. International journal of training and development, 8(1), 8-20.

Smith, E. A. (2001). The role of tacit and explicit knowledge in the workplace. Journal of Knowledge Management, 5(4), 311-321.

Streumer, J. N., \& van der Klink, M. R. (2001). De werkplek als leeromgeving [The work placement as a learning environment]. Pedagogische Studiën, 78(2), 79-85.

Taris, T. W. (2007). Al doende leert men. Werkkenmerken en leergedrag op het werk. [Learning by doing. Work characteristics and learning behaviour at work] Lecture by Prof. T. Taris, hoogleraar Arbeidsmotivatie [Senior Lecturer in Employment Motivation], Radboud Universiteit Nijmegen, 29 November 2007.

Taris, T. W., \& Kompier, M. A. J. (2005). Job characteristics and learning behaviour: Review and psychological mechanisms. In P. L. Perrewé \& D. C. Ganster (Eds.), Research in occupational stress and well-being: Exploring interpersonal dynamic (Vol. 4, pp. 127-166). Amsterdam: JAI Press.

Taris, T. W., Kompier, M. A. J., De Lange, A. H., Schaufeli, W. B., \& Schreurs, P. J. G. (2003). Learning new behaviour patterns: a longitudinal test of Karasek's learning hypothesis among Dutch teachers. Work \& Stress, 17(1), 1-20.

Taris, T. W., Kompier, M., \& Wielenga-Meijer, E. (2006). Leren op het werk: een handelingstheoretisch perspectief [Learning at work: an activity-based theory perspective]. Gedrag en Organisatie [Behaviour and organisation], 19, 69-90.

Tynjälä, P. (2008). Perspectives into learning at the workplace. Educatonal Research Review, 2(3), $130-151$.

Van Loo, J. (2005). Training, Labour Market Oucomes, and Self-management. Doctoral dissertation. Research Centre for Education and the Labour Market. Utrecht: Universiteit Utrecht.

Warr, P. B. (1990). The measurement of well-being and other aspects of mental health. Journal of Occupational Psychology, 63, 193-210. 
David Gijbels is assistant professor at the institute for Education and Information Sciences at the University of Antwerp, Belgium. His research and development interests focus on learning and assessment in higher education and the working life.

Isabel Raemdonck is assistant professor at the University of Leiden, The Netherlands. Her research interests focus on adult education and self-directed learning.

Dries Vervecken is researcher at the Free University of Berlin. His research interests focus on professional competences. 